\title{
Effect of Foliar Application of Nutrients and Growth Regulator on Fruit Quality of Pomegranate cv. Bhagwa
}

\author{
Ulfatullah $^{1}$, Satpal Baloda ${ }^{1}$, S. K. Sehrawat ${ }^{1}$, J. R. Sharma ${ }^{1}$, G. S. Rana ${ }^{1}$, \\ Arvind Malik ${ }^{1}$ and Jayanti Tokas ${ }^{2}$ \\ ${ }^{1}$ Department of Horticulture, ${ }^{2}$ Department of Biochemistry, CCS Haryana Agricultural \\ University, Hisar-125004, Haryana, India
}

*Corresponding author

\section{Keywords}

Pomegranate, nutrients, growth regulator, fruit quality

Article Info

Accepted:

22 April 2021

Available Online:

10 May 2021
The experiment comprising of eleven treatments of nutrients and growth regulator was conducted on seven years old plants at Experimental Orchard of the Department of Horticulture, CCS Haryana Agricultural University, Hisar during the year 2019-20 to study the effect of urea, $\mathrm{ZnSO}_{4}$ and NAA on fruit quality of pomegranate. The data were recorded on total soluble solids $\left(\mathrm{B}^{0}\right)$, total sugars $(\%)$, reducing sugars (\%), non reducing sugars (\%), acidity (\%), aril $(\%)$, peel (\%), juice $(\%)$, anthocyanin content $(\mathrm{mg} / 100 \mathrm{~g})$ and fruit colour. The recorded data were subjected to statistical analysis using RBD. The result of the experiment indicates that the foliar application of urea, $\mathrm{ZnSO}_{4}$, and NAA had a significantly positive effect on most of the recorded parameters. The maximum potential of pomegranate plants in respect of fruit TSS (14.6 $\%)$, total sugars $(12.80 \%)$, reducing sugar $(10.90 \%)$, non reducing sugars $(1.90 \%)$, aril $(61.8 \%)$, juice $(35.2 \%)$, anthocyanin content $(15.42 \mathrm{mg} / 100 \mathrm{~g})$, fruit colour (4.00 visual scored) was exploited to a maximum level and acidity $(0.68 \%)$, peel $(38.2 \%)$ to a minimum level with foliar application of urea $1.0 \%+\mathrm{ZnSO}_{4} 0.5 \%$.

\section{Introduction}

Pomegranate (Punica granatum L.) is an important fruit crop of the tropical and subtropical regions of the world. Among various arid fruits, it occupies second largest area after ber Sutanu et al., (2017). It can tolerate a little frost and grows up to an altitude of 1600 meters from mean sea level (MSL), however, in humid areas its quality is not desirable. The tree is deciduous in area where the temperature is low in winter, but in tropical condition it is evergreen as partially deciduous. It can tolerate alkaline and wet 
soil. In India, total area under this fruit at present accounted to be 209 thousand ha with an annual production of 2442 thousand MT Anonymous, (2017). Pomegranate is one of the more nutritional fruit and is capable of growing in different agro-climatic conditions ranging from tropical to sub-tropical. India is the largest producer of pomegranate in the world and commercially cultivated in Maharashtra, Andhra Pradesh, Rajasthan, Gujarat, Karnataka, Tamil Nadu and UP. The most important cultivar in this belt is 'Bhagwa' which covers around 80 per cent area under pomegranate in Maharashtra. Pomegranate is one of the richest sources of Riboflavin. The edible part of the fruit is called arils which are eaten fresh and can be preserved as syrup or used for making jam. Anthocyanin in pomegranate arils is a rich source of antioxidants. The edible parts of fruit contain considerable amount of carbohydrates, proteins, minerals, vitamins, sugars and polysaccharides. The total sugars, reducing sugars, non-reducing sugars, ascorbic acid, acidity, and total soluble solids etc., are important components determining quality of fruit juice in pomegranate Hasani et al., (2012). The juice is considered useful for patients suffering from leprosy, dysentery and diarrhea also pomegranate juice contains higher levels of antioxidants than most other fruit juices. The antioxidants in pomegranate juice can help remove free radicals, protect cells from damage and reduce inflammation.

Use of nutrients and growth regulators has also been reported effective in improving yield and quality of pomegranate Davarpanah et al., (2016). Zinc is an important nutrient element for growth, flowering and quality of fruits Rana and Rawat, (2016). Nitrogen is most important macro element in plants that play a key role in quality characters Wahdan et al., (2011). NAA is an important growth regulator of auxin group, which helps to improve fruit set and quality of fruit. Therefore, effective nutrients and growth regulator management in pomegranate, which involves finding of appropriate rate, time and method of application as well as selection of suitable combination of fertilizers and growth regulator is required to get desired quality fruits. Although, the effect of foliar applied chemicals and growth regulator on quality and physiological traits of pomegranate have been studied by many workers in different parts of the world and the information of such effect on pomegranate fruit is very scanty in case of Haryana and a little work is carried out on this crop. Keeping in view the above facts, the present investigation was carried out to complement the available information on this aspect under Hisar condition.

\section{Materials and Methods}

The experiment was carried out at Experimental Orchard and in Post-Harvest Technology Laboratory of the Department of Horticulture, CCS Haryana Agricultural University, Hisar during the year 2019-20. These plants were earmarked in January 2019 for collecting the data on various quality parameters. Hisar has a typical semi-arid climate with hot and dry summer and extremely cold winter. The mean monthly maximum and minimum temperatures show an extensive range of variations both during summer and winter months. The eleven fertilizer and growth regulator treatments in different combinations were laid out in randomized block design with three replications. Seven years old uniformly grown trees spaced at $5 \times 5 \mathrm{~m}$ were selected for the present study. Plants were kept under uniform orchard management practices during the study, where all the cultural practices were carried out as per package of practices. The observations were recorded on TSS $\left(\mathrm{B}^{0}\right)$, total sugars $(\%)$, reducing sugars $(\%)$, non reducing sugars $(\%)$, acidity, aril (\%), peel (\%) juice $(\%)$, anthocyanin content $(\mathrm{mg} / 100 \mathrm{~g})$ and fruit 
colour (visual observation). The recorded data were subjected to statistical analysis by using the technique of analysis of variance.

\section{Results and Discussion}

The data pertaining to the effect of different nutrients and growth regulator on TSS, total sugars, reducing sugars and non-reducing sugars in pomegranate cv. Bhagwa are presented in (Table.1). It is evident from data that application of zinc sulphate, urea, NAA and their combination at different concentration induced significant effect on Total soluble solids (TSS) \%, total sugar (\%), reducing sugars $(\%)$, non-reducing sugars $(\%)$ of fruits. The TSS under various treatments ranged from $12.2 \%$ to $14.6 \%$, total sugars from $10.40 \%$ to $12.80 \%$, reducing sugars from $9.46 \%$ to $10.90 \%$, non reducing sugars $0.94 \%$ to $1.90 \%$. Maximum TSS (14.6\%), total sugars (12.80), reducing sugars (10.90), non reducing sugars (1.90) was recorded with treatment $\left(\mathrm{T}_{11}\right)$. However, minimum TSS (12.2\%), total sugars (10.40), reducing sugars (9.46), non reducing sugars (0.94) were observed in control. From the perusal of data on the effect of different nutrients, plant growth regulator and their combination on titrable acidity in pomegranate $\mathrm{cv}$. Bhagwa are presented in (Table.1) revealed that application of NAA, zinc sulphate, urea and their combination at different concentration exerted significant effect on titrable acidity. The titrable acidity under various treatments ranged from $1.14 \%$ to $0.68 \%$. The least values of acidity $0.68 \%$ was recorded in treatment $\mathrm{T}_{11}$ ( $1 \%$ Urea $+0.5 \% \mathrm{ZnSO}_{4}$ ). However maximum titrable acidity $(1.14 \%)$ was recorded with treatment control.

The results obtained from the present study in (Table 1) revealed that the maximum total soluble solids, total sugar, reducing sugar, non reducing sugar and minimum acidity was recorded in fruits harvested from trees sprayed with combined nutrients application of $1 \%$ urea $+0.5 \% \quad \mathrm{ZnSO}_{4}$ and was quite effective in case of these quality parameters. The maximum TSS due to the combined nutrients application might be due to the increased photosynthesis activity, translocation of sugars from source to the sink and converting of complex form of sugars (polysaccharides) to simple sugars (glucose and fructose) in fruits Eman et al., (2007), due to the increased activities of enzymes by zinc. Zinc is also an important nutrient element for growth, flowering and quality of fruits. It is involved in the biosynthesis of plant hormone Indole acetic acid. Zinc plays an important role in nucleic acid and protein synthesis and helps in the utilization of phosphorous and nitrogen Rana and Rawat, (2016). Nitrogen is most important macro element in plants that play a key role in quality characters like total soluble solids contents in fruits due to the functioning of number of enzymes might than been stimulated, affecting the physiological processes, which in turn hydrolyzed starch and helped in metabolic activity during the change available starch into sugar and Soluble solids contents by foliar application of urea Wahdan et al., (2011). Increase in TSS might be due to spray of urea which helps in sugar transport ultimate accumulation of more sugars in fruits. It's action on changing complex materials into simple ones, which improves the metabolic activity in fruits. Increasing total sugar is due to either quickly converted into sugars and their derivatives by reactions involving reverse glycolytic pathways or might have been used in respiration or both Singh et al., (2017).

The results of present investigation are supported by the findings of Obaid and AlHadethi (2013) reported that $\mathrm{Zn}$ and $\mathrm{Mn}$ sprays had significant positive effects on TSS in Salemy cultivars of pomegranate and the effect of $\mathrm{Zn}$ was more reasonable than $\mathrm{Mn}$ in increasing TSS, but their combination at 
concentration resulted in relatively higher TSS, the quality improvement in fruits may be due to proper supply of nutrients and induction of growth hormones, which stimulates cell division, cell elongation, increase in weight of fruits, better translocation of water uptake and deposition of nutrients. Balakrishnan et al., (1996) who reported that the highest TSS was obtained by foliar application of zinc sulfate combined with boric acid and decrease acidity in 'Ganesh' pomegranate. The increase in TSS may be accounted to the hydrolysis of the polysaccharides, conversion of organic acid into soluble sugars and enhanced solubilization of insoluble starch and pectin present in cell wall and middle lamella Jain, (2006). El-Khawga (2007) noticed that the quality parameters are significantly affected by foliar application of $\mathrm{ZnSO}_{4}$ in pomegranate and reported highest total soluble solids, maximum total sugars maximum reducing sugars and minimum acidity. The enhancement in quality of fruit could be due to the catalytic action of micronutrients particularly at higher concentration. Hence the foliar application of micronutrients quickly increased the uptake of macronutrients in all the tissues and organs and improves fruit quality Alila and Achumi (2012). Davarpanah (2016) who reported that the amount of total sugars in pomegranate cv. Ardestani fruit juice increased significantly only in the case of the combined $\mathrm{Zn}=1.8 \mathrm{mM}+\mathrm{B}=0.6 \mathrm{mM}$ treatments. Dewangan (2014) noticed the maximum TSS, reducing sugars, total sugars and non-reducing sugars with application of $\mathrm{ZnSO}_{4} @ 0.5 \%+\mathrm{FeSO}_{4} @ 0.5 \%$ + boric acid @ $0.3 \%$ in pomegranate. Hasani et al., (2012) who reported that titrable acidity significantly reduced by foliar application of $0.6 \% \mathrm{ZnSO}_{4}$ in pomegranate. The minimum acidity due to $\mathrm{ZnSO}_{4}$ foliar spray in fruit juice because of nutrients foliar application might be due to the metabolic conversion of organic acids into sugars and rapid utilization of organic acids in respiration Brahmahachari et al., (1997).

The data regarding the effect of foliar application of plant growth regulator and different nutrients on aril $(\%)$, juice $(\%)$, peel $(\%)$, anthocyanin content $(\mathrm{mg} / 100 \mathrm{~g})$ and fruit colour in pomegranate cv. Bhagwa are presented in (Table 2). It is clear from data that application of NAA, zinc sulphate, urea and their combination at different concentrations exerted significant effect on mentioned parameters of pomegranate. The aril per cent under various treatments ranged from $50.1 \%$ to $61.8 \%$, juice from $28.5 \%$ to $35.2 \%$. Maximum aril per cent $(61.8 \%)$ and juice per cent $(35.2 \%)$ was recorded with treatment $\mathrm{T}_{11} \quad\left(1 \%\right.$ Urea $\left.+0.5 \% \quad \mathrm{ZnSO}_{4}\right)$, However, minimum aril per cent $(50.1 \%)$ and juice per cent $(28.5 \%)$ was observed in the treatment control. The data regarding peel per cent are presented in (table 2) showed that peel per cent under various treatments ranged from $49.9 \%$ to $38.2 \%$. The minimum peel per cent $(38.2 \%)$ was recorded with treatment $\mathrm{T}_{11}\left(1 \%\right.$ Urea $\left.+0.5 \% \quad \mathrm{ZnSO}_{4}\right)$, However, maximum peel per cent $(49.9 \%)$ was recorded in the treatment control.

The data regarding the effect of foliar application of plant growth regulator and different nutrients on anthocyanin content of Pomegranate cv. Bhagwa are presented in (Table 2). The anthocyanin content under various treatments ranged from 15.10 $\mathrm{mg} / 100 \mathrm{~g}$ to $15.51 \mathrm{mg} / 100 \mathrm{~g}$. Maximum anthocyanin content $(15.51 \mathrm{mg} / 100 \mathrm{~g})$ was recorded with treatment $\mathrm{T}_{7}(40 \mathrm{ppm}$ NAA), However, minimum anthocyanin content $(15.10 \mathrm{mg} / 100 \mathrm{~g})$ was recorded in the treatment control. 
Table.1 Effect of nutrients and growth regulator on TSS, acidity and sugars of Pomegranate cv. Bhagwa

\begin{tabular}{|c|c|c|c|c|c|c|}
\hline No & Treatment & $\begin{array}{l}\text { TSS } \\
(\%)\end{array}$ & $\begin{array}{c}\text { Total } \\
\text { sugars }(\%)\end{array}$ & $\begin{array}{c}\text { Reducing } \\
\text { sugars } \\
(\%)\end{array}$ & $\begin{array}{c}\text { Non } \\
\text { reducing } \\
\text { sugars }(\%)\end{array}$ & $\begin{array}{c}\text { Acidity } \\
(\%)\end{array}$ \\
\hline$T_{1}$ & Control & 12.2 & 10.40 & 9.46 & 0.94 & 1.14 \\
\hline $\mathbf{T}_{2}$ & $0.5 \%$ Urea & 13.0 & 10.99 & 10.03 & 0.96 & 1.08 \\
\hline$T_{3}$ & $1 \%$ Urea & 13.1 & 11.20 & 10.20 & 1.00 & 1.04 \\
\hline $\mathbf{T}_{4}$ & $0.25 \% \mathrm{ZnSO}_{4}$ & 13.3 & 11.50 & 10.30 & 1.20 & 1.02 \\
\hline $\mathbf{T}_{5}$ & $0.50 \% \mathrm{ZnSO}_{4}$ & 13.5 & 11.70 & 10.36 & 1.34 & 0.97 \\
\hline$T_{6}$ & $20 \mathrm{ppm}$ NAA & 14.2 & 12.33 & 10.56 & 1.77 & 0.86 \\
\hline $\mathbf{T}_{7}$ & 40 ppm NAA & 14.3 & 12.40 & 10.63 & 1.77 & 0.80 \\
\hline $\mathbf{T}_{8}$ & $\begin{array}{c}0.5 \% \text { Urea+0.25\% } \\
\mathrm{ZnSO}_{4}\end{array}$ & 13.8 & 12.00 & 10.46 & 1.54 & 0.94 \\
\hline $\mathbf{T}_{9}$ & $\begin{array}{c}0.5 \% \text { Urea }+0.5 \% \\
\mathrm{ZnSO}_{4}\end{array}$ & 14.0 & 12.20 & 10.50 & 1.70 & 0.90 \\
\hline$T_{10}$ & $\begin{array}{c}1 \% \text { Urea }+0.25 \% \\
\mathrm{ZnSO}_{4}\end{array}$ & 14.4 & 12.50 & 10.70 & 1.80 & 0.76 \\
\hline \multirow[t]{2}{*}{$\mathbf{T}_{11}$} & $\begin{array}{c}1 \% \text { Urea }+0.5 \% \\
\mathrm{ZnsSO}_{4}\end{array}$ & 14.6 & 12.80 & 10.90 & 1.90 & 0.68 \\
\hline & C.D. at $5 \%$ & 0.8 & 0.90 & 0.70 & 0.20 & 0.10 \\
\hline
\end{tabular}

Table.2 Effect of nutrients and growth regulator on aril, peel, juice, anthocyanin and fruit colour of Pomegranate cv. Bhagwa

\begin{tabular}{|c|c|c|c|c|c|c|}
\hline No & Treatment & $\begin{array}{c}\text { Aril } \\
(\mathbf{\%})\end{array}$ & $\begin{array}{c}\text { Peel } \\
(\mathbf{\%})\end{array}$ & $\begin{array}{c}\text { Juice } \\
(\mathbf{\%})\end{array}$ & $\begin{array}{c}\text { Anthocyanin } \\
\text { content } \\
(\mathbf{m g} / \mathbf{1 0 0 g})\end{array}$ & $\begin{array}{c}\text { Fruit colour } \\
\text { (Visual } \\
\text { observation) }\end{array}$ \\
\hline $\mathbf{T}_{\mathbf{1}}$ & Control & 50.1 & 49.9 & 28.5 & 15.10 & 2.36 \\
\hline $\mathbf{T}_{\mathbf{2}}$ & $0.5 \%$ Urea & 55.6 & 44.4 & 31.6 & 15.25 & 3.06 \\
\hline $\mathbf{T}_{\mathbf{3}}$ & $1 \%$ Urea & 56.1 & 43.9 & 31.9 & 15.33 & 3.66 \\
\hline $\mathbf{T}_{\mathbf{4}}$ & $0.25 \% \mathrm{ZnSO}_{4}$ & 53.5 & 46.5 & 30.4 & 15.18 & 2.62 \\
\hline $\mathbf{T}_{\mathbf{5}}$ & $0.50 \% \mathrm{ZnSO}_{4}$ & 54.8 & 45.2 & 31.2 & 15.21 & 2.96 \\
\hline $\mathbf{T}_{\mathbf{6}}$ & $20 \mathrm{ppm} \mathrm{NAA}$ & 60.1 & 39.9 & 34.2 & 15.43 & 2.41 \\
\hline $\mathbf{T}_{\mathbf{7}}$ & $40 \mathrm{ppm} \mathrm{NAA}$ & 61.6 & 38.4 & 35.0 & 15.51 & 2.48 \\
\hline $\mathbf{T}_{\mathbf{8}}$ & 0.5\%Urea+0.25\% & 56.7 & 43.3 & 32.2 & 15.28 & 3.66 \\
\hline & ZnSO & & & & & \\
\hline $\mathbf{T}_{\mathbf{9}}$ & 0.5\%Urea+0.5\% $\mathrm{ZnSO}_{4}$ & 57.4 & 42.6 & 32.7 & 15.33 & 3.66 \\
\hline $\mathbf{T}_{\mathbf{1 0}}$ & $1 \%$ Urea +0.25\% $\mathrm{ZnSO}_{4}$ & 61.3 & 38.7 & 34.9 & 15.38 & 4.00 \\
\hline $\mathbf{T}_{\mathbf{1 1}}$ & $1 \%$ Urea +0.5\% $\mathrm{ZnSO}_{4}$ & 61.8 & 38.2 & 35.2 & 15.42 & 4.00 \\
\hline & C.D. at 5\% & 2.1 & 1.4 & 1.4 & 0.10 & 0.10 \\
\hline
\end{tabular}


Fig.1 Effect of nutrients and growth regulator on TSS \% of Pomegranate cv. Bhagwa

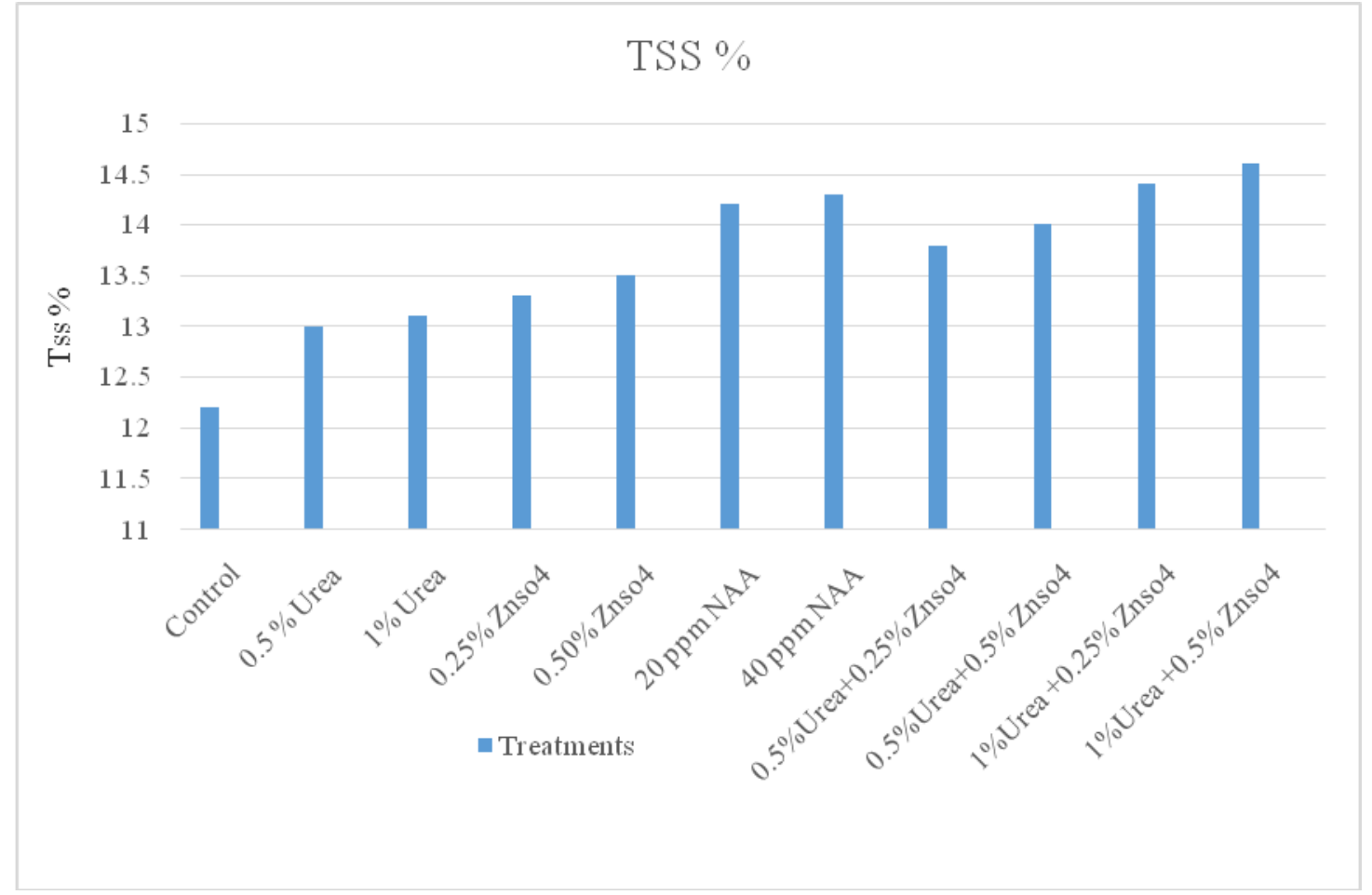

Fig.2 Effect of nutrients and growth regulator on aril, juice and peel \% of Pomegranate cv. Bhagwa

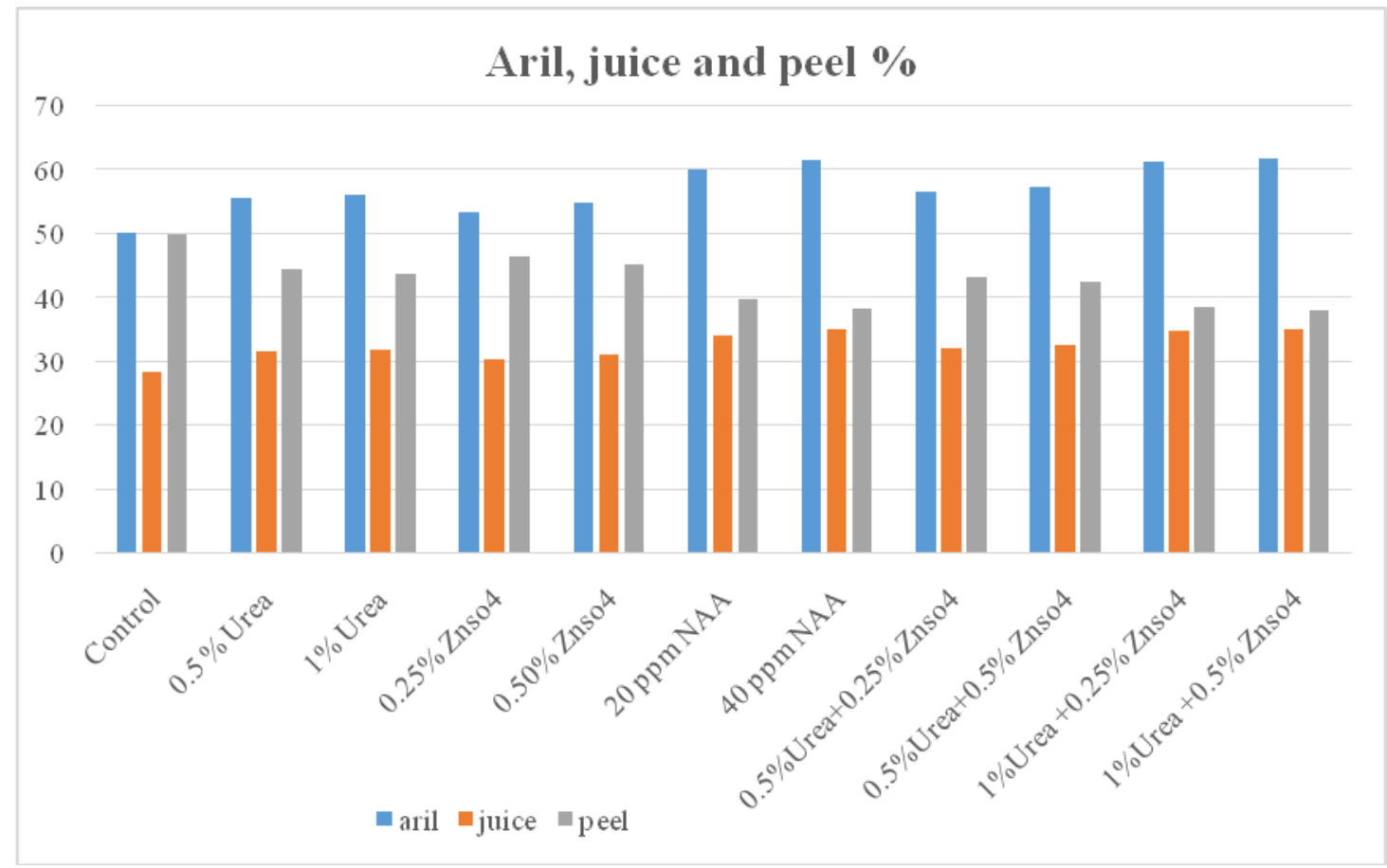


The data regarding fruit colour are presented in (table 2) showed that fruit colour under various treatments exhibited significant effect on fruit colour of pomegranate. Results showed the positive effect of chemicals and growth regulators on fruit coloration of pomegranate, and were assessed an arbitory four-point system was followed to evaluate the fruit colour. The treatments $\mathrm{T}_{10}(1 \%$ urea $\left.+0.25 \% \mathrm{ZnSO}_{4}\right), \mathrm{T}_{11}\left(1 \%\right.$ urea $\left.+0.5 \% \mathrm{ZnSO}_{4}\right)$ yielded high coloured by enhancing maximum score (4.0) and moderately coloured yielded in control by enhancing minimum score $(2.36)$.

The significantly maximum juice and aril per cent of pomegranate fruits was obtained with foliar combined nutrient application of $1 \%$ urea $+0.5 \% \mathrm{ZnSO}_{4}$ (Table. 2). The increase in juice content in fruits might be attributed to the fact that zinc might have regulated the water relations in plants, increases in mineral concentrations in cells after fertilization can increase turgor pressure and stimulate water absorption Kumar et al., (2014). The results of present investigation are in agreement with the findings of Hasani et al., (2012) who reported that application of $\mathrm{ZnSO}_{4}$ at concentration $0.3 \%$ significantly increased juice content of arils. Combination of manganese sulfate at $0.6 \%$ and zinc sulfate at $0.3 \%$ was the best treatment on increasing juice content of arils and anthocyanin index in pomegranate. Masoud et al., (2019) who found that foliar application of $\mathrm{GA}_{3}$ at 50 ppm singly or combined with $\mathrm{CaCl}_{2} 2 \%$ and $\mathrm{ZnSO}_{4} 0.25 \%$ gave the highest values of juice in pomegranate. The peel content of pomegranate significantly affected by foliar application of urea, $\mathrm{ZnSO}_{4}$ and NAA and also with their combined application in various concentration and are presented in (Table 2) and it was significantly reduced. The minimum peel content of pomegranate was recorded in fruits harvested from trees sprayed with combined nutrients application of $1 \%$ urea+0.5\% $\mathrm{ZnSO}_{4}$ and was quite effective in reducing peel content of pomegranate. The result of present investigation is in close conformity with the findings of Khalil and Aly (2013) who reported fruit peel per cent had the highest values with untreated trees, while, the lowest were obtained from trees sprayed with 300 ppm paclobutrazol treatment and obtained from foliar application of $\mathrm{ZnSO}_{4}$ at concentration $(0.3 \%)$ in Pomegranate cv. Manfalouty. Davarpanah et al., (2016) who reported that the minimum peel per cent in pomegranate was obtained by $2 \%$ foliar application of urea.

The significantly maximum anthocyanin content of pomegranate fruits was obtained with foliar application of 20 ppm NAA and 40 ppm NAA. The results of present investigation are supported by the findings of Khalil and Aly (2013) who reported that application of 40 ppm NAA in Pomegranate cv. Manfalouty increased total anthocyanin as compared to control. The Results of present investigation showed the positive effect of chemicals and growth regulators on fruit coloration of pomegranate. The trees treated with $1 \%$ urea $+0.5 \% \quad \mathrm{ZnSO}_{4}$ yielded high coloured by enhancing maximum score. Since the colour of fruit depend on many environmental factors (e.g., light, temperature), tree vigor and mineral nutrition Sala et al., (1992) among it nutrient elements nitrogen fertilization influences the different aspects of fruit quality from fruit morphology (length, width, weight of the fruit, etc.), juice chemical composition ( $\mathrm{pH}$, TSS, total titratable acid, organic acids, anthocyanin, and total polyphenols) and organoleptic properties.

The anthocyanins are found in larger quantity in the peel and determine the color. Total polyphenols, also found in greater amounts in the peel normally increase as response to $\mathrm{N}$ fertilization and contribute to color intensity and taste characteristics of fruit. The reason behind colour development could be increase in starch degradation and carotenoid content with the application of chemicals. 


\section{References}

Alila, P. and Achumi, I. 2012. Pre-harvest chemical treatments affect post-harvest quality of litchi fruit. Acta Horticulture, 934: 755-761.

Anonymous 2017.Area and production of pomegranate in India during 201718.Data year book of National Horticultural Board, Gurgon (Haryana) India.

Balakrishnan, K., Venkatesan, K. and Sambandamurti, S. 1996. Effect of foliar application of $\mathrm{Zn}, \mathrm{Fe}, \mathrm{Mn}$ and B on yield and quality of pomegranate cv. Ganesh. Orissa Journal of Horticulture, 24(1): 33-35.

Brahmachari, V. S., Yadav, G. S. and Naresh, K. 1997. Effect of feeding of calcium, zinc and boron on yield and quality attributes of litchi (Litchi chinensis Sonn.). Orissa Journal of Horticulture, 25(1): 49-52.

Davarpanah, S., Tehranifar, A., Davarynejad, G., Abadía, J. and Khorasani, R. 2016. Effects of foliar applications of zinc and boron nano-fertilizers on pomegranate (Punica granatum cv. Ardestani) fruit yield and quality. Scientia Horticulture, 210: 57-64.

Dewangan, M. 2014.Effect of foliar application of different chemicals on yield and quality of pomegranate (Punica granatum L.) cv. Bhagwa. M.Sc. thesis submitted to College of Agriculture, Latur, VNMKV, Parbhani.

El-Khawga, A. S. 2007. Reduction in fruit cracking in Manfalouty pomegranate following a foliar application with paclobutrazol and zinc sulphate. Journal of Applied Science Research, 3(9): 837-840.

Eman, A. A. A. E., El-Migeed, M. M. M. A. and Omayma, M. M. I. 2007. $\mathrm{GA}_{3}$ and zinc sprays for improving yield and fruit quality of Washington navel orange trees grown under sandy soil conditions. Research Journal of Agriculture and Biological Sciences, 3(5): 498-503.

Hasani, M., Zamami, Z., Savaghebi, G. and Fatahi, R. 2012 Effects of zinc and manganese as foliar spray on pomegranate yield, fruit quality and leaf minerals. Journal of Soil Science and Plant Nutrition, 12(3): 471-480.

Jain, P. K. 2006. Fruit drop, yield and quality of mango as influenced by biozyme and urea sprays. Indian Journal of Horticulture, 63(4): 453-454.

Khalil, H. A. and Aly, H. S. 2013. Cracking and fruit quality of pomegranate (Punica granatum L.) as affected by pre-harvest sprays of some growth regulators and mineral nutrients. Journal of Horticultural Science and Ornamental Plants, 5(2): 71-76.

Kumar, M., R. Dwivedi, A. K. Anand and Kumar, A. 2014. Effect of nutrient on physicochemical characteristics of phalsa (Grewia subinaequalis D.C.) fruits. Global Journal of Bioscience and Biotechnology, 3:320-323

Masoud, A. A. B., Ibraheem, F. E. and Khodair, O. A. 2019. Effect of gibberellic acid, naphthalenacetic acid, calcium and zinc spraying on fruiting of Manfalouty, pomegranate Trees. Assian Journal of Agricultural Sciences, 50(2): 219-228.

Obaid, E. A. and Al-Hadethi, M. E. A. 2013. Effect of foliar application with manganese and zinc on pomegranate growth, yield and fruit quality. Journal of Horticulture Science and Applied plants, 5(1): 41-45.

Rana, D. K. and Rawat, S. S. 2016. Effect of foliar application of zinc and boron on yield and quality of pomegranate (Punica granatum L.) cv. Ganesh under sub-tropical conditions of 
Garhwal hills. HortFlora Research Spectrum, 5(1): 61-64.

Sala, J. M., Cunat, P., Collado, M. and Momcholli, V. 1992. Effect of nitrogenous fertilization (quality and $\mathrm{N}$ form) on precocity of colour change of 'Valencia' oranges. International Society of Citriculture, 2: 598-602.

Singh, B., Singh, R. and Barholia, A. K. 2017. Response of guava to foliar application of urea, potassium sulphate and borax on growth and fruit yield. Crop Research, 52(6): 229-233.
Sutanu, M., Aniruddha, Y. and Meena, K. R. 2017. Effect of calcium and boron on growth, yield and quality of pomegranate (Punicagranatum L.). International Journal of Plant Sciences (Muzaffarnagar), 12(2): 108-113.

Wahdan, M. T., Habib, S. E., Bassal, M. A. and Qaoud, E. M. 2011. Effect of some chemicals on growth, fruiting, yield and fruit quality of Mango cv." SuccaryAbiad". Journal of American Science, 7(2): 651-658.

\section{How to cite this article:}

Ulfatullah, Satpal Baloda, S. K. Sehrawat, J. R. Sharma, G. S. Rana, Arvind Malik and Jayanti Tokas. 2021. Effect of Foliar Application of Nutrients and Growth Regulator on Fruit Quality of Pomegranate Cv. Bhagwa. Int.J.Curr.Microbiol.App.Sci. 10(05): 615-623. doi: https://doi.org/10.20546/ijcmas.2021.1005.069 